\title{
ANALISIS KOMPARASI KERAGAAN USAHA BUDIDAYA IKAN LELE MUTIARA (Clarias gariepinus) DENGAN DAN TANPA SISTEM BIOFLOK
}

\section{COMPARATIVE ANALYSIS OF PERFORMANCE GROWING BUSINESS OF MUTIARA CATFISH (Clarias gariepinus) WITH AND WITHOUT BIOFLOC SYSTEM}

\author{
Achmad Rizal $^{1 *}$, AyiYustiati ${ }^{1)}$, Asep Agus Handaka Suryana ${ }^{1)}$, Reno DwiPutro ${ }^{1)}$ \\ ${ }^{1)}$ Fakulktas Perikanan dan Ilmu Kelautan Universitas Padjadjaran \\ Jl. Raya Bandung-Sumedang Km 21 Jatinangor, Sumedang
}

\begin{abstract}
Abstrak
Penelitian ini dilakukan di 2 (dua) lokasi di Kabupaten Bogor, yaitu di P2MKP Mina Srikandi pembudidaya ikan lele menggunakan sistem bioflok yang berada di Kecamatan Cibinong dan CV Sumber Rejeki pembudidaya ikan lele tanpa menggunakan sistem bioflok yang berada di Kecamatan Gunung Sindur. Penelitian ini bertujuan untuk membandingkan struktur biaya dan pendapatan usaha budidaya serta menganalisis efisiensi budidaya ikan lele menggunakan sistem bioflok dan tanpa bioflok. Berdasarkan hasil analisis perhitungan tingkat pendapatan menunjukan perbedaan secara signifikan antara tingkat pendapatan pembudidaya ikan lele yang menggunakan sistem bioflok dan tanpa bioflok. Rata-rata pendapatan pembudidaya ikan lele menggunakan sistem bioflok dalam satu siklus usaha budidaya (tiga bulan) pada kolam berukuran $7 \mathrm{~m}^{2}$ adalah Rp. 984.233 dengan rata-rata jumlah produksi sebesar $315 \mathrm{~kg}$ dan produktifitas kolam $45 \mathrm{~kg} / \mathrm{m}^{2}$. Sementara rata-rata tingkat pendapatan pembudidaya ikan lele tanpa sistem bioflok pada kolam berukuran $7 \mathrm{~m}^{2}$ adalah $\mathrm{Rp}$. 294.233 , dengan rata-rata jumlah produksi sebesar $302,5 \mathrm{~kg}$ dan produktifitas kolam $43 \mathrm{~kg} / \mathrm{m}^{2}$. Penerapan teknologi bioflok mampu mampu menurunkan nilai FCR serta meningkatkan efisiensi pakan.
\end{abstract}

Kata Kunci :bioflok, pendapatan, ikan lele

\begin{abstract}
This research was conducted at two (2) locations in Bogor, at P2MKP Mina Srikandi catfish farmers using biofloc systems in Cibinong district and CV. Sumber Rejeki catfish farmers without using biofloc systems in Gunung Sindur district. The research aims are to compare the cost and revenue structure of farming as well as to analyze the efficiency of catfish aquaculture using biofloc and without biofloc systems Calculation analysis shows a difference between the level of incomes of catfish farmers using biofloc and who are not using biofloc system. the average income of beneficiary catfish farmers using biofloc system in one cycle of business (three months) in a pool measuring 7 $\mathrm{m}^{2}$ is Rp. 984.233 with $315 \mathrm{~kg}$ of the average of total production and $45 \mathrm{~kg} / \mathrm{m}^{2}$ of productivity, while the average of income level of catfish farmers without biofloc system in a pool measuring $7 \mathrm{~m}^{2}$ is Rp. 294.233 with $302,5 \mathrm{~kg}$ of the average of total production and $43 \mathrm{~kg} / \mathrm{m}^{2}$ of productivity. The application of biofloc technology can reduce the value of FCR and increase feed efficiency.
\end{abstract}

Keywords :biofloc, income, catfish

\section{Pendahuluan}

Ikan lele (Clarias sp) merupakan komoditas budidaya ikan air tawar yang memiliki rasa enak, harga relatif murah, kandungan gizi tinggi, pertumbuhan cepat, mudah berkembangbiak, toleran terhadap mutu air yang kurang baik, relatif tahan terhadap penyakit dan dapat dipelihara hampir di semua wadah budidaya (Nasrudin, 2010). Dari keunggulan tersebut maka usaha budidaya ikan lele merupakan peluang bisnis yang bagus dan dapat meningkatkan pendapatan. Banyak orang yang beranggapan bahwa budidaya ikan lele dapat dilakukan dengan mudah, pernyataan tersebut dikatakan benar manakala ditinjau dari faktor teknis, sebab ikan lele merupakan jenis ikan yang 
mudah dibudidayakan, toleran terhadap mutu air yang kurang baik, tahan terhadap penyakit, dapat ditebar dengan kepadatan tinggi dan pertumbuhannya yang cepat. Tetapi pada kenyataan dilapangan menunjukan bahwa tidak semua orang yang terjun di usaha pembesaran ikan lele dapat memperoleh keuntungan sesuai dengan yang diharapkan (Prihartono dkk, 2010).

si ikan lele cenderung menurun setiap tahunnya, hal ini dikarenakan secara umum kapasitas usaha yang dijalankan masih dalam skala kecil. Disisi lain tingginya cost produksi sebagai akibat dari tingginya harga pakan pabrikan secara langsung berpengaruh terhadap margin keuntungan yang didapat (KKP, 2013). Oleh karena dibutuhkan penguasaan teknologi apabila ingin melakukan usaha pembesaran ikan lele. Interaksi dengan sesama pembudidaya ikan lele sangatlah penting untuk menunjang keberhasilan pembesaran ikan lele, hal ini dapat dilakukan dengan bertukar informasi tentang benih yang baik, pakan yang bermutu dan lain sebagainya yang menunjang keberhasilan dalam usaha pembesaran ikan lele. Inovasi diperlukan untuk meningkatkan produksi ikan lele salah satunya terhadap efisiensi biaya penggunaan pakan agar memperoleh keuntungan yang lebih besar.

Direktorat Jenderal Perikanan Budidaya, Kementrian Kelautan dan Perikanan (DJPB,KKP) menyampaikan capaian produksi ikan lele pada tahun 2013 mampu melampaui target yang telah ditetapkan, yaitu dengan capaian $(108,35 \%)$ yang diikuti oleh capaian produksi yang mencapai $140,86 \%$ dari target, hal tersebut terjadi berkat adanya langkahlangkah strategis yaitu : 1) Pengembangan budidaya secara intensifikasi dengan bioflok untuk efisiensi pakan. 2) Penggunaan teknologi budidaya ikan lele dengan terpal sebagai upaya efesiensi pemanfaatan lahan. 3) Extensifikasi melalui program Pengembangan Usaha Mina Pedesaan (PUMP) Perikanan Budidaya.

Berdasarkan langkah - langkah strategis yang telah ditempuh dapat dibuktikan bahwa teknologi bioflok merupakan jalan keluar untuk meningkatkan produksi ikan lele khususnya pada efisiensi penggunaan pakan. Budidaya ikan dengan menerapkan teknologi bioflok berarti memperbanyak bakteri/mikroba yang menguntungkan dalam media budidaya ikan, sehingga dapat memperbaiki dan menjaga kestabilan mutu air, menekan senyawa beracun seperti amoniak, menekan perkembangan bakteri yang merugikan (bersifat pathogen) sehingga ikan dapat tumbuh dan berkembang dengan baik. Dalam beberapa tahun terakhir, teknologi biofloc (BFT) dalam budidaya (BFT-aquaculture)telah mendapat perhatian di seluruh dunia (Luo, et.al., 2017).

Teknologi bioflok merupakan salah satu alternatif baru dalam mengalasi masalah kualitas air dalam akuakultur yang diadaptasi dari teknik pengolahan limbah domestik secara konvensional (Avnimelech, 2009; De Schryver et al., 2008). Hal ini berarti bioflok merupakan salah satu pemanfaatan teknologi yang mampu mengolah limbah untuk meminimalkan limbah sekaligus mendaur ulang limbah menjadi pakan. Hal ini merupakan jalan keluar dalam menciptakan budidaya ikan yang ramah lingkungan, berkelanjutan, efisien dalam penggunaan air maupun pakan. Penelitian ini bertujuan untuk membandingkan struktur biaya, pendapatan usaha, dan efisiensi budidaya ikan lele menggunakan sistem bioflok, yaitu di Pusat Pelatihan Mandiri Kelautan dan Perikanan (P2MKP) Mina Srikandi dan tanpa bioflok, yaitu di P2MKP Sumber Rejeki,kedua tempat tersebut terletak di kabupaten bogor.

\section{Metode Penelitian}

Penelitian ini dilaksakan pada bulan Agustus 2016 sampai dengan bulan Agustus 2017 yang dilaksanakan di P2MKP Mina Srikandi dan Sumber Rejeki yang berlokasi di Kabupaten Bogor, Jawa Barat. Metode penelitian yang digunakan adalah observasi langsung/survei ke lapangan.Objek yang diteliti dalam penelitian ini adalah perbandingan efisiensi usaha dan perbandingan jumlah pendapatan antara pembudidaya ikan lele menggunakan teknik bioflok dan tanpa bioflok.Pengambilan sampel dalam penelitian ini menggunakan metode purposive sampling. Purposive sampling merupakan teknik pengambilan sampel sumber data dengan pertimbangan tertentu yakni sumber data dianggap paling tahu tentang apa yang diharapkan, sehingga mempermudah peneliti menjelajahi objek (Singarimbun dan Effendi, 2008).

Perhitungan tingkat pendapatan pembudidaya ikan lele dengan dan tanpa 
sistem bioflok dapatdiperoleh dengan menghitung keuntungan yang diperoleh dengan mengurangkan biaya yang dikeluarkan selama proses produksi dengan penerimaan, yaitu $\mathrm{I}=\mathrm{TR}-\mathrm{TC}$, dimana $\mathrm{I}=$ Pendapatan $(\mathrm{Rp}) ; \mathrm{TR}=$ Total Penerimaan $(\mathrm{Rp}) ; \mathrm{TC}=$ Total Biaya (Rp).

Perhitungan total biaya yang keluarkan oleh pembudidaya ikan lele dengan dan tanpa sistem bioflok. Biaya tetap meliputi biaya pemeliharaan kolam dan biaya penyusutan dari kolam dan peralatan budidaya.Biaya variabel meliputi biaya yang dikeluarkan oleh pengusaha budidaya untuk penyediaan benih, pakan, vitamin dan obatobatan.Berikut merupakan rumus yang dapat digunakan (Suparmoko, 2001), yaitu $\mathrm{TC}=$ TFC + TVC, dimana TC = Total Biaya $(\mathrm{Rp})$; TFC Total Biaya Tetap (Rp); TVC $=$ Total Biaya Variabel (Rp).

Penerimaan kotor usaha budidaya ikan lele adalah jumlah produksi yang dihasilkan dalam suatu kegiatan usaha budidaya dikalikan dengan harga jual yang berlaku di pasaran. Pernyataan ini dapat ditulis sebagai berikut (Siregar 2009), yaitu TR = Q x P, dimana, TR $=$ Total Revenue/Penerimaan $(\mathrm{Rp} /$ tahun $) ; \mathrm{Q}=$ Jumlah Produksi per tahun ; P = Harga (Rp).

Selanjutnya digunakan analisis untuk mengetahui biaya-biaya yang dikeluarkan dalam usaha budidaya ikan lele. Biaya adalah semua nilai faktor produksi yang dipergunakan untuk menghasilkan suatu produk dalam suatu periode tertentu yang dinyatakan dalam nilai uang tertentu.Oleh karena itu perlu diperhitungkan biaya penyusutan. Biaya penyusutan alat-alat budidaya ikan diperhitungkan dengan membagi selisih antara nilai pembelian dengan sisa yang ditafsirkan dengan lamanya modal yang dipakai (Metode Garis Lurus), dengan rumus sebagai berikut :
Biaya penyusutan $=(\mathrm{Nb}-\mathrm{Ns}) / \mathrm{n}$, dimana $\mathrm{Nb}=$ Nilai pemblian $(\mathrm{Rp})$; $\mathrm{Ns}=$ Tafsiran nilai sisa (Rp); $\mathrm{n}=$ Jangka usia ekonomi (tahun)

Analisis R/C rasio adalah rasio penerimaan atas biaya yang menunjukan besarnya tambahan penerimaan yang diperoleh dari setiap rupiah yang dikeluarkan dalam produksi.Hal ini menunjukkan berapa besar tambahan penerimaan yang diperoleh sebagai manfaat di setiap rupiah yang dikeluarkan.Makin besar R/C makin baik usaha budidaya tersebut. Untuk mengetahui tingkat keberhasilan pembudidaya, digunakan rumus sebagai berikut : $\quad \mathrm{R} / \mathrm{C}$ ratio $=\mathrm{R} / \mathrm{C}$, dimana $\mathrm{R}=$ Total penerimaan usaha budidaya; $\mathrm{C}=$ Total biaya usaha budidaya.

Apabila $\mathrm{R} / \mathrm{C}$ ratio $>1$ maka suatu usaha dikatakan afisien.Hal ini menunjukkan semakin tinggi nilai $\mathrm{R} / \mathrm{C}$ maka tingkat pengembalian yang diterima pembudidaya ikan lele untuk setiap satu rupiah biaya yang dikeluarkan adalah semakin tinggi.Jika R/C <1 maka usaha ini tidak efisien artinya pembudidaya mengalami kerugian, karena penerimaan yang diterima oleh pembudidaya lebih kecil daripada biaya yang dikeluarkan oleh pembudidaya. Dan apabila $\mathrm{R} / \mathrm{C}=1$ maka pembudidaya tidak untung dan tidak rugi (Soekartawi, 2006; Dessy, 2016).

\section{Hasil}

Analisis Pendapatan dilakukan terhadap biaya produksi yang mencakup biaya variabel dan biaya tetap yang dilakukan dalam satu periode.Biaya investasi yang dikeluarkan oleh P2MKP Mina Srikandi per kolam dalam satu siklus adalah sebesar Rp. 4.055.767, biaya tersebut merupakan biaya sewa lahan per kolam dan penyusutan kolam dalam satu siklus produksi (3 bulan) (Tabel 1).

Tabel 1. Analisa Pendapatan P2MKP Mina Srikandi per kolam

\begin{tabular}{lcccc}
\hline Keterangan & Unit (Satuan) & Harga/satuan $(\mathrm{Rp})$ & UmurEkonomis & Total \\
\hline $\begin{array}{l}\text { BiayaTetap } \\
\text { PenyusutanKola }\end{array}$ & 1 buah & 2.261 .000 & 5 th & 113.050 \\
$\begin{array}{l}\text { SewaLahan } \\
\text { BiayaVariabel }\end{array}$ & $1500 \mathrm{~m}^{2}$ & 15.000 .000 & 1 th & 37.500 \\
PakanApung & & & & \\
Bibit & $240 \mathrm{~kg}$ & 9500 & & 2.280 .000 \\
Probiotik & $3000 \mathrm{ekor}$ & 250 & & 750.000 \\
TenagaKerja & $1,5 \mathrm{Liter}$ & 100.000 & & 150.000 \\
\hline TOTAL BIAYA & 11 Orang & 65.928 & & $\mathbf{4 . 0 5 5 . 7 6 7}$ \\
\hline
\end{tabular}


Total biaya variabel yang dikeluarkan dalam satu periode (3bulan) yaitu sebesar $\mathrm{Rp}$ 3.905.217. Terdapat 5 komponen yang menjadi biaya variabel dalam usaha pembesaran ikan lele di P2MKP Mina Srikandi antara lain pakan, bibit, probiotik sebagai suplemen dan tenaga kerja.Sementara biaya tetap yang dikeluarkan oleh P2MKP
Sumber Rejeki per kolam dalam satu siklus (3 bulan) adalah Rp. 4.545.767.Total biaya variabel yang dikeluarkan dalam satu periode (3bulan) yaitu sebesar Rp 4.095.217. Terdapat 5 komponen yang menjadi biaya variabel dalam usaha pembesaran ikan lele Sumber Rejeki antara lain pakan, bibit, probiotik, obatobatan dan tenaga kerja (Tabel 2).

Tabel 2. Biaya Tetap dan Biaya Variabel pembesaran ikan lele di P2MKP Sumber Rejeki

\begin{tabular}{|c|c|c|c|c|}
\hline Keterangan & Unit (Satuan) & Harga/satuan (Rp) & UmurEkonomis & Total \\
\hline \multicolumn{5}{|l|}{ BiayaTetap } \\
\hline $\begin{array}{l}\text { PenyusutanKola } \\
\mathrm{m}\end{array}$ & 1 buah & 2.261 .000 & 3 th & 113.050 \\
\hline $\begin{array}{l}\text { SewaLahan } \\
\text { PerawatanKola }\end{array}$ & $1500 \mathrm{~m}^{2}$ & 15.000 .000 & 1 th & $\begin{array}{c}37.500 \\
300.000\end{array}$ \\
\hline \multicolumn{5}{|l|}{ BiayaVariabel } \\
\hline Pakan & $240 \mathrm{~kg}$ & 9500 & & 2.280 .000 \\
\hline Bibit & 3.000 ekor & 250 & & 750.000 \\
\hline Probiotik & 2 Liter & 100.000 & & 200.000 \\
\hline Obat-obatan & & & & 140.000 \\
\hline TenagaKerja & 11 Orang & 65.928 & & 725.217 \\
\hline TOTAL BIAYA & & & & 4.545.767 \\
\hline
\end{tabular}

\section{Pembahasan}

\section{Pendapatan}

Analisis pendapatan digunakan untuk mengetahui nilai pendapatan yang diperoleh dari penerimaan dalam satu periode.Penerimaan usaha pembesaran lele yang dilakukan oleh P2MKP Mina Srikandi dalam satu periode diperoleh dari penjualan ikan lele siap konsumsi dalam satu periode. Dari 3.000 bibit ikan lele yang dibesarkan oleh P2MKP Mina Srikandi selama satu periode menghasilkan $315 \mathrm{Kg}$ ikan lele siap konsumsi, harga $1 \mathrm{Kg}$ ikan lele yang dijual oleh P2MKP Mina Srikandi yaitu Rp. 16.000, sehingga penerimaan yang didapat dalam satu periode sebesar Rp. 5.040.000.Total pendapatan yang diperoleh P2MKP Mina Srikandi dalam satu periode sebesar Rp. 984.233. Pendapatan ini diperoleh dari selisih total penerimaan dan total biaya usaha pembesaran ikan lele dalam satu periode (Tabel 3).

Bibit ikan lele yang dibesarkan oleh Sumber Rejeki yaitu 3.000 bibit, selama satu periode menghasilkan $302,5 \mathrm{Kg}$ ikan lele siap konsumsi, harga $1 \mathrm{Kg}$ ikan lele yang dijual oleh Sumber Rejeki yaitu Rp. 16.000
Sehingga penerimaan yang didapat dalam satu periode sebesar Rp. 4.840 .000 (Tabel 4).

Tabel 3. Penerimaan usaha pembesaran lele P2MKP Mina Srikandi

\begin{tabular}{ll}
\hline Uraian & Jumlah $(\mathrm{Rp})$ \\
\hline Total Penerimaan & 5.040 .000 \\
Total Biaya & 4.055 .767 \\
Total Pendapatan & 984.233 \\
\hline
\end{tabular}

Tabel 4. Total pendapatan atau keuntungan P2MKP Mina Srikandi

\begin{tabular}{ll}
\hline Uraian & Jumlah $(\mathrm{Rp})$ \\
\hline Total Penerimaan & 4.840 .000 \\
Total Biaya & 4.545 .767 \\
Total Pendapatan & 294.233 \\
\hline
\end{tabular}

\section{Analisis R/C Rasio}

Penerimaan yang diperoleh P2MKP Mina Srikandi dalam satu periode sebesar Rp. 5.040.000 sedangkan total biaya yang dikeluarkan dalam satu periode sebesar Rp. 4.055.767. Dengan demikian dapat dinilai R/C Ratio yang diperoleh P2MKP Mina Srikandi sebesar 1,24 menunjukan bahwa R/C > 1 , maka usaha budidaya ikan lele yang 
dilaksanakan oleh P2MKP Mina Srikandi efisien dan layak diusahakan (Tabel 5).

Tabel 5. Total penerimaan dan R/C perbandingan

\begin{tabular}{lcc}
\hline Uraian & $\begin{array}{c}\text { P2MKP } \\
\text { Mina } \\
\text { Srikandi }\end{array}$ & $\begin{array}{c}\text { Sumber } \\
\text { Rejeki }\end{array}$ \\
\hline Total Penerimaan & 5.040 .000 & 4.840 .000 \\
Total Biaya & 4.055 .767 & 4.545 .767 \\
R/C Ratio & 1,24 & 1,06 \\
\hline
\end{tabular}

Berdasarkan data Tabel 5 diketahui bahwa penerimaan yang diperoleh Sumber Rejeki dalam satu periode sebesar Rp.4.840.000. sedangkan total biaya yang dikeluarkan dalam satu periode sebesar Rp. 4.545.767, dengan demikian dapat dinilai R/C Rasio yang diperoleh Sumber Rejeki sebesar 1,06 menunjukan bahwa R/C > 1, maka usaha budidaya ikan lele yang dilaksanakan oleh Sumber Rejeki efisien dan layak diusahakan tetapi $\mathrm{R} / \mathrm{C}$ rasio pembudidaya menggunakan sistem bioflok lebih besar yaitu sebesar 1,24 yang berarti pembudidaya ikan lele menggunakkan sistem bioflok memiliki kelayakan usaha yang lebih baik daripada pembudidaya ikan lele tanpa sistem bioflok.

\section{Analisis Efisiensi}

Pendapatan pembudidaya ikan lele menggunakan sistem bioflok dan konvensional didapat dari selisih antara penerimaan dengan total biaya pengeluaran yang dinyatakan dalam rupiah per siklus usaha budidaya (selama 3 bulan). Dari hasil penelitian dapat diketahui bahwa produksi, biaya produksi, penerimaan dan pendapatan yang diterima oleh pembudidaya menunjukan jumlah yang berbeda.
Berdasarkan data perbandingan pada Tabel 6 diketahui bahwa budidaya ikan lele menggunakan sistem bioflok lebih efisien pada teknis, hal ini dibuktikan dengan kolam berukuran $7 \mathrm{~m}^{2}$ mampu memproduksi sebesar $315 \mathrm{~kg}$ per siklus budidaya (selama 3 bulan), dengan rata-rata produktifitas sebesar 45 $\mathrm{kg} / \mathrm{m}^{2}$, sedangkan pada budidaya ikan lele konvensional mampu memproduksi sebesar $302,5 \mathrm{~kg}$ per siklus budidaya (selama 3 bulan) pada kolam berukuran $7 \mathrm{~m}^{2}$, dengan rata-rata produktifitas $43 \mathrm{~kg} / \mathrm{m}^{2}$.

Jumlah produksi dan pendapatan yang menunjukkan angka lebih besar dapat dipengaruhi oleh beberapa faktor, diantaranya penerapan teknologi bioflokpada sistem budidaya mampu menurunkan nilai FCR dan meningkatkan efisiensi pakan.Hal ini tidak terlepas dari kontribusi meningkatnyabiomassa mikroorganisme flok bernutrisi tinggi yang terbentuk karena adanya penambahan karbohidrat dan peningkatan rasio $\mathrm{C} / \mathrm{N}$ pada media budidaya (Widanarni dkk, 2009) menyatakan bahwa efisiensi pakan dengan aplikasi bioflok lebih tinggi karena adanya peningkatan biomassa mikroba bioflok sebagai sumber nutrisi atau makanan tambahan untuk ikan.

Pada hasil analisis menunjukkan bahwa nilai FCR pembudidaya ikan menggunakkan teknologi bioflok lebih rendah yaitu $0,8 \mathrm{~kg}$ pakan berbanding $1 \mathrm{~kg}$ ikan, sedangkan pada pembudidaya ikan tanpa menggunakkan teknologi bioflok yaitu $1,1 \mathrm{~kg}$ pakan berbanding $1 \mathrm{~kg}$ ikan (Avnimelech, 2009).

Tabel 6. Perbandingan Efisiensi P2MKP Mina Srikandi dan Seumber Rejeki

\begin{tabular}{lccc}
\hline \multicolumn{1}{c}{ Aspek } & $\begin{array}{c}\text { P2MKP Mina } \\
\text { Srikandi }\end{array}$ & SumberRejeki & Keterangan \\
\hline JumlahProduksi & $315 \mathrm{Kg}$ & $302,5 \mathrm{Kg}$ & \\
Produktifitas & 45 & 43 & $\mathrm{Kg} / \mathrm{m}^{2}$ \\
Biaya & Rp. 579.395 & $\mathrm{Rp} .649 .395$ & $\mathrm{Rp} / \mathrm{m}^{2}$ \\
Penerimaan & Rp. 720.000 & $\mathrm{Rp} .691 .428$ & $\mathrm{Rp} / \mathrm{m}^{2}$ \\
Pendapatan & Rp. 140.604 & Rp. 42.033 & $\mathrm{Rp} / \mathrm{m}^{2}$ \\
R/C Ratio & 1,24 & 1,06 & $>1:$ Untung \\
\hline
\end{tabular}




\section{Kesimpulan}

Berdasarkan penelitian di lapangan dan hasil pengolahan data yang telah dilakukan dengan membandingkan struktur biaya, pendapatan dan efisiensi budidaya ikan lele menggunakan sistem bioflok dan tanpa bioflok maka dapat diperoleh kesimpulan sebagai berikut:

1. Pendapatan pembudidaya ikan lele dengan menggunakan sistem bioflok adalah sebesar Rp. $140.604 / \mathrm{m}^{2}$ dengan rata-rata jumlah produksi $315 \mathrm{~kg}$, dan produktifitas kolam $45 \mathrm{~kg} / \mathrm{m}^{2}$ sedangkan rata-rata tingkat pendapatan pembudidaya ikan lele tanpa sistem bioflok adalah sebesar Rp. 42.033 $/ \mathrm{m}^{2}$ dengan jumlah produksi sebesar 302,5 $\mathrm{kg}$ dan produktifitas kolam $43 \mathrm{~kg} / \mathrm{m}^{2}$. Jumlah tersebut menunjukan bahwa sistem bioflok lebih efisien dari segi teknis dan finansial.

2. Perbedaan jumlah pendapatan antara pembudidaya ikan lele menggunakan sistem bioflok dan tanpa bioflok dipengaruhi oleh beberapa faktor, diantaranya adalah pembudidaya ikan lele menggunakan sistem bioflok biaya lahan yang lebih kecil sehingga biaya sewa lahan lebih rendah serta perawatan pada kolam pun jauh lebih mudah dibandingkan dengan kolam pembudidaya ikan lele konvensional, penerapan teknologi bioflok mampu menurunkan nilai FCR dan meningkatkan efisiensi pakan karena meningkatnya biomassa mikroorganisme flok. Nilai FCR pembudidaya ikan lele menggunakan teknologi bioflok lebih rendah yaitu $0,8: 1$ sedangkan nilai FCR pada pembudidaya non bioflok yaitu $1,1: 1$.

\section{Daftar Pustaka}

Avnimelech, Y. (2009). Biofloc Technology: A Practical Guide Book. World Aquaculture Society : Louisiana, USA.

De Schryver, P., R. Crab, T. Defoirdt, N. Boon, and W. Verstraete.(2008). The
Basics of Bio-flocsTechnology: The Added Value for Aquaculture. Journal of Aquaculture, 227 : 125-137.

Dessy R.A. (2016).Komparasi Pendapatan Usaha Ternak Ayam Ras Pedaging Pola Kemitraan dan Mandiri. Tesis (tidak dipublikasikan), Institut Pertanian Bogor, Bogor.

Direktorat Jenderal Perikanan Budidaya.(2013). Laporan Tahunan Direktorat Produksi Tahun 2013. Jakarta.http://dx.doi.org/10.1016/j.aquaen g.2017.01.001 0

Luo, Guozhi,Nan Zhang, Hongxin Tan, Zhiwei Hou, Wenchang Liu. (2017). Efficiency of producing bioflocs with aquaculture waste by using polyhydroxybutyric acid as a carbon source in suspended growth bioreactors.Aquacultural Engineering, 76, 34-40.

Nasrudin.(2010). Jurus Sukses Beternak Lele Sangkuriang. Penerbit Agromedia Pustaka, Jakarta.

Prihartono, E, Juansyah $\mathrm{R}$ dan A. Usnie. (2010). Mengatasi Permasalahan Budidaya Lele. Penerbit PT Penebar Swadaya, Jakarta.

Singarimbun, Masri dan Effendi.S.(2008). Metode Penelitian Survai. Pustaka LP3ES Indonesia, Jakarta.

Siregar, KDW. (2009). Analisis Sistem Kemitraan Dalam Meningkatkan Pendapatan Peternak Ayam Pedaging Di Kabupaten Deli Serdang : Studi Kasus Peternak Kemitraan PT. Jepfa Comfeed Indonesia. Skripsi (tidak dipublikasikan). Universitas Sumatera Utara. Medan.

Soekartawi. (2006). Analisis Usahatani. Jakarta. UI Press

Widanarni, D. Wahjuningrum dan M. Setiawati. (2009). Optimasi Budidaya Super Intensif Ikan Nila Ramah Lingkungan: Dinamika Mikroba Bioflok.Tesis (tidak dipublikasikan). Fakultas Perikanan dan Ilmu Kelautan, Institut Pertanian Bogor, Bogor. 